\title{
A conceptually based model of the interaction between flowing meltwater and subglacial sediment
}

\author{
David N. Collins \\ Alpine Glacier Project, Department of Geography, University of Manchester, Manchester M13 9PL, England
}

\begin{abstract}
Detailed measurements of sediment flux in meltwaters draining from the portal of Gornergletscher, Valais, Switzerland, each ablation season between 1987 and 1990 indicate the nature of interactions between the developing basal drainage system and sediment stored at the glacier subsole. Sediment-flux maxima, which were generally smaller and less frequent later in a season, occurred at times of rising discharge. Overall, sediment flux first increased then decreased during a season. A simple conceptually based model is proposed for the subglacial interaction between flowing meltwater and sediment derived from glacial abrasion. The model was developed in order to allow investigation of relationships between suspended-sediment flux and discharge in meltwaters draining from temperate glaciers. In the model, water spreads out over a grid-square bed such that the area of subsole integrated with flow is a function of discharge. Sediment is abraded from the bed at a uniform rate in cells not covered by water. In winter, sediment accumulates over almost all the bed. Periods of rising flow at the start of the ablation season lead to drainage net expansion, much entrainment of stored sediment and large flux events in portal meltwaters. The model allows redistribution and deformation of stored sediment in two directions. Sediment squeezed to the margins of the wetted area throughout summer provides the background level of sediment flux between events. Reduction in total channel-margin length with progressive changes in drainage-network topology explains declining background flux later in summer. The model replicates well the timing, but not the absolute and relative magnitudes, of sediment-flux maxima in portal meltwaters draining from Gornergletscher.
\end{abstract}

\section{INTRODUCTION}

The large quantities of sediment transported in the discharge from temperate glaciers indicate that flow occurs over the subsole for much of the distance between where meltwaters descend from the surface and emerge at the ice margin. Sediment produced by glacial erosion processes is picked up by such water flowing at the subsole. Entrainment of products of abrasion is unlikely to be distributed uniformly across the subsole, as meltwaters usually emerge from a glacier in distinct filaments of flow which probably cover only a small proportion of the basal area. Not all filaments will flow with sufficient velocity to entrain all sizes of particles. Sediment will therefore accumulate at the subsole where meltwater flow is either absent or inadequate for entrainment.

Transport of debris by meltwater from glacier subsoles is distributed irregularly in time. In winter, both overall discharge and velocities in individual branches of the drainage network are too low for entrainment of even fine sediment. As flow rises, with increasing input of energy for melting, in spring and early summer, disproportionately large quantities of suspended sediment are transported by comparison with those moved by higher flows later in the season (Collins, 1990). Either availabillity of subglacial sediment to meltwater is reduced during the season
(Ostrem, 1975), or the supply of sediment becomes exhausted. Major spatial instabilities of the basal drainage network punctuate the seasonal pattern of sediment flux with spikes, particularly in the early part of the season (Collins, 1989). These subglacial hydrological events occur when flowing meltwaters first impinge on areas of subsole where sediment accumulated during a long period of hydraulic isolation.

Different aliquots of meltwater having differing possibilities of access to sediment for entrainment has frustrated modelling of suspended-sediment transport in streams draining temperate glaciers. Discharge has normally been taken as the forcing variable, usually in simple regression of suspended-sediment concentration against discharge (e.g. Ostrem, 1975; Collins, 1979). Not only is the fit of such rating curves generally poor but the model parameters change during ablation seasons. Transfer-function models relating sediment concentration to discharge (e.g. Gurnell and Fenn, 1984) also fail to cope with major events and declining sediment availability during summer.

The aim of this contribution is to develop a conceptual model of the interaction of flow through the basal hydrological network with the production and storage of glacially eroded sediment at the sole of a temperate glacier. Sediment will accumulate where water does not 
flow. Accumulating wet sediment will deform and interact with flowing meltwater. This interaction not only can determine the form of elements of the subglacial drainage network under steady-state conditions, as envisaged by Walder and Fowler (1994), but will also influence suspended-sediment transport in meltwaters under transient-flow regimes. The temporal pattern of suspended-sediment flux in the Gornera, the only meltstream draining from Gornergletscher, Valais, Switzerland, in the 1987-90 ablation seasons, provided the rationale for the formulation of the model. The basin of $82 \mathrm{~km}^{2}$ is about $84 \%$ glacierized.

\section{MEASUREMENTS}

Samples of meltwater and suspended sediment were collected from the Gornera, using a Manning S4050 automatic pumping sampler located at the gauging station $0.75 \mathrm{~km}$ from the terminus of Gornergletscher. The intention was to collect samples at hourly intervals, $24 \mathrm{hd}^{-1}$, between May and September each year. Samples were filtered through individually pre-weighed cellulose acetate circles which, together with the sediment retained, were dried before reweighing. Occasionally, samples were lost because of equipment malfunction or processing accident. Hourly total sediment flux was calculated from instantaneous sediment concentration $\left(\mathrm{kg} \mathrm{m}^{-3}\right)$ and hourly mean discharge $\left(\mathrm{m}^{3} \mathrm{~s}^{-1}\right)$. Full details of the methods are given by Collins (1989).

\section{RESULTS AND INTERPRETATION}

Temporal patterns of suspended-sediment flux and discharge indicate how the developing drainage system interacts with sediment stored at the glacier subsole. Fluxes of sediment and water in the Gornera during the 1987-90 ablation seasons are shown in Figure 1. The 1987-89 series has been described in detail by Collins (1989, 1990, 1991). Salient features of basal watersediment interaction can be discerned from sequences of discharge fluctuations and temporal variations of sediment flux, both within individual ablation seasons and throughout the 4 year period. Subglacial spatial-instability events are identified when sediment flux rises for a few days above the general background level for a particular part of a season.

During the 4 years, almost all large sediment-flux events occurred at times of generally rising discharge. In general, large events were less frequent later in an ablation season. When they did happen late in summer, they were often associated with precipitation and were not just the result of subglacial process interactions. A major sediment-flux event occurred on 30 June 1987 as discharge increased above $10^{6} \mathrm{~m}^{3} \mathrm{~d}^{-1}$ for the first time, in response to thermal inputs. A swath of glacier subsole was swept of sediment which had accumulated during the winter low-flow period. A similar event accompanied flow rising to higher levels on 5-7 July, but substantially less sediment was flushed from the bed. The area of "fresh" subsole from which sediment was flushed was smaller than

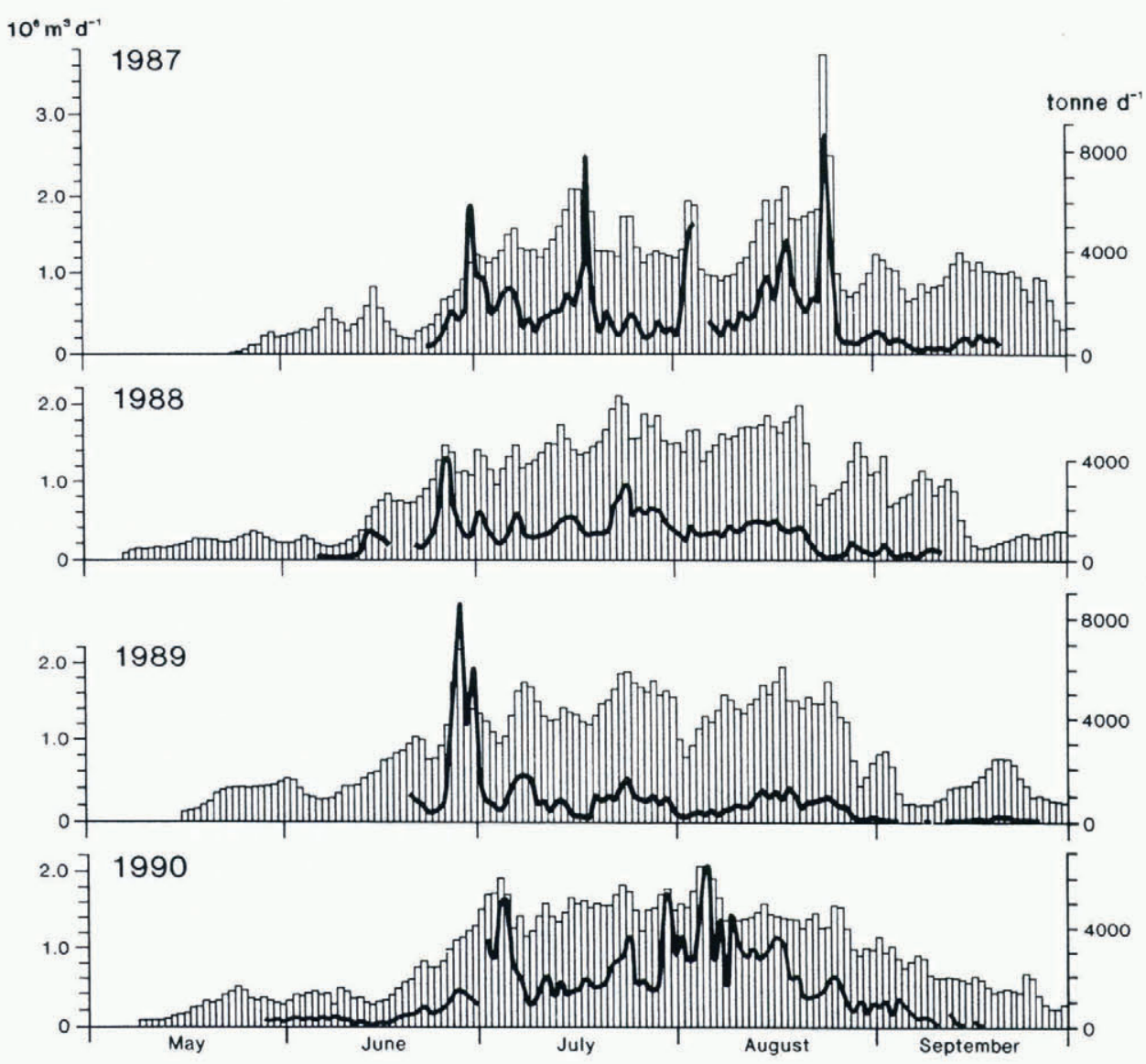

Fig. 1. Daily total discharge (columns) and measured daily total suspended-sediment flux (curves) in the Gornera, Valais. Switzerland, in the months May-September in the years 1987-90. 
that integrated during the first event. Although discharge remained at relatively high levels, sediment flux fell sharply after both events. Rainfall over much of the Gornergletscher basin between 15 and 18 July contributed to runoff which was already rising after several warm days. A sediment-flux event (above $8 \mathrm{kt} \mathrm{d}^{-1}$ ) was triggered as discharge exceeded previous levels of 1987 . More rain on 24-25 July enhanced runoff, although the previous daily maximum was not reached. A minor fluctuation in background sediment flux suggests that runoff from rainfall over the unvegetated ice-free area entrained little sediment. Drainage of the marginal ice-dammed Gornersee on 2-4 August produced a maximum sediment flux above $5 \mathrm{ktd}^{-1}$, although discharge failed to exceed previous levels. Sediment must have been derived from areas of subsole which remained stocked between the lake and the existing swept zone, which had been flushed of sediment earlier in the season. On 18 August, thermally induced rising discharge exceeded the previous maximum, producing a significant flux event as flow enlarged the wetted area into fresh subsole. Finally, a rainstorm on 23-24 August, which produced floods with 10-30 year recurrence intervals in the Swiss Alps (Collins, 1995), induced the highest daily totals of both discharge and sediment flux $(8.574 \mathrm{kt})$ in the Gornera in 1987. In September, background sediment fluxes remained at low levels $\left(<1 \mathrm{kt} \mathrm{d}^{-1}\right)$ in comparison with those measured in July and early August.

Sediment-flux events were muted in 1988, although background flux was sustained at around $1 \mathrm{kt} \mathrm{d}^{-1}$ until late August. The first major steep increase in discharge, on 24-25 June, swept a significant portion of the subsole, after which subsequent increases in discharge were tracked by small sediment-flux fluctuations. Flows between 19 and 24 July, the highest since August 1987, produced a maximum daily flux of only $2.965 \mathrm{kt}$, rainfall towards the end of the event notwithstanding. Subsole sediment storage was so depleted during 1987 that a total discharge between June and September 1988 only slightly less than that in the same period in 1987 transported only two-thirds of the sediment load of the previous year. Nevertheless, as in all other years, the proportion of the annual total sediment load transported by a given date in the ablation season was greater than the proportion of the annual total runoff discharged (Fig. 2).

During a period of thermally forced rising discharge, the Gornersee drained on 27-29 June 1989, producing the highest daily total discharge since August 1987. Simultaneous timing of the lake-burst with the first integration of

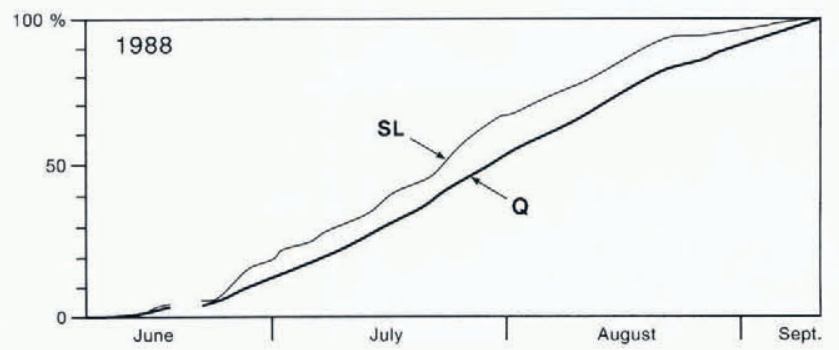

Fig. 2. Percentages of the ablation-season totals of discharge (Q) and sediment load (SL) of the Gornera cumulated by day for 1988 . the bed with flow after the winter sediment recharge period produced the highest daily flux total in the 4 years. Although, subsequently, discharge reached successively higher levels on three occasions, tracked by sediment flux, fluxes remained lower than $2 \mathrm{ktd}^{-1}$ throughout the remainder of the season. Sediment had been flushed from a large proportion of the subsole area by the end of June. A combination of thermally forced rising discharge and drainage of the Gornersee also produced the first sediment-flux event of 1990 between 2 and 4 July, but maximum discharge was less than in 1989. Subsequent variations in discharge were tracked by sediment flux, with significant events on 20-22 and 29-31 July. However, discharge failed to surpass maxima earlier in the season. The highest discharge of 1990 produced a major event with peak sediment flux of $6.42 \mathrm{kt} \mathrm{d}^{-1}$ on 4 August. This was followed by two smaller events. Rainfall played a role in the event of 6 August.

\section{SUBGLACIAL ENTRAINMENT OF SEDIMENT BY MELTWATER}

Significant high-magnitude sediment-flux events occur each time discharge exceeds levels that have not been reached for some time. Filaments of flow beneath the ice successively expand the area of subsole wetted to incorporate progressively parts of the subsole which have remained hydraulically isolated for sufficiently long to allow large quantities of sediment to be produced by glacial abrasion and to accumulate. Flux events represent stages in the seasonal evolution of the basal drainage system. The drainage network expands areally to accommodate increasing flows of meltwater through individual reaches and to drain an expanding surface area of bare ice, as the transient snow-line migrates in response to depletion of the winter snow cover. As discharge increases, filaments of flow widen from the initial wetted area to integrate marginal areas of subsole. When flow declines with the return of cooler hydrometeorological conditions, the wetted area contracts, and filaments of flow presumably return to the subsole locations occupied previously at a given level of discharge. Removal of fine sediment from areas of subsole marginal to a filament of flow will result from growth of the cross-sectional area. Exploitation of sediment at the bed and release of any debris in the basal ice layer by melting of the ice forming the roof over a channel are favoured by the width of a filament of flow expanding at a greater rate than the depth, for example in a lenticular cross-sectional area or where channels widen by entraining basal layer sediment in preference to melting ice. Some increases in discharge evidently do not result in sediment-flux events. During such increases, the drainage net remains within the boundaries of the recently swept area of subsole. Conversely, some areas of hydraulically isolated subsole charged with sediment evidently become integrated, as filaments of flow can be displaced without need for an increase in discharge.

The measured flux of suspended sediment at times before, between and after events requires continuous sediment delivery to basal meltwaters, although the actual quantity supplied declines towards the end of a 
season. Some sediment will be acquired from channel margins as diurnal variations in discharge change the wetted area. Movement of filaments of flow with respect to stored sediment is brought about both by sliding of the channels across the subsole with the ice mass as a whole, and by shifting of channels with respect to the glacier through melting of tunnel ice-walls by flowing meltwater. Sweeping of sediment from the bed will be more effective if the drainage-network topology consists of many channels arranged transverse to the direction of sliding, for example in a herring-bone pattern. Accumulated wet basal sediment will also be deformed into hydrological pathways at channel margins.

\section{MODEL DEVELOPMENT}

\section{Sediment-flux events}

A conceptually based model of meltwater-sediment interaction at the base of a glacier has to enable production and accumulation of sediment across the subsole and allow meltwater access to sediment from areas which have not been integrated with flow for some time. This is modelled by allowing the wetted area of bed to vary with discharge. The model consists of a gridsquare lattice which represents the subsole of a rectangular valley glacier (Fig. 3). The lattice is tilted at a low angle, down-glacier, towards one of the shorter sides. In winter, the small water flow is restricted to the long axis of the grid. This axis forms the thalweg of a valley, which has a gently sloping parabolic crosssection, in which the glacier sits. An abrasion rate (producing $A \mathrm{~g} \mathrm{~d}^{-1}$ area $^{-1}$ of uniform-sized silt) is applied uniformly in space and time to all cells in the lattice not occupied by meltwater in each $1 \mathrm{~d}$ time increment. Charging of a cell starts after the last inundation by meltwater in summer, and continues throughout winter so that, by the onset of melt in the following spring, substantial quantities of sediment will have accumulated across the entire subsole (Fig. 3a).

Spreading of the total wetted area with discharge in spring and summer is represented by the margins of a zone accommodating flow moving out equally on both sides of and in parallel with the long axis centre line or thalweg, throughout the length of the lattice. The intention is to represent as one band the total net effect of what in Nature will be many small areas occupied by separate filaments of flow. All the sediment accumulated in a cell is entrained when meltwater first occupies the cell, so that the wetted area becomes sediment-free (Fig. 3b). Each successive expansion of wetted area produces a sediment-flux event, the size of which is determined by integration of the quantity of sediment stored over the newly wetted area at the outer margin. Where previous discharge levels are only little exceeded, in mid-summer, and the newly wetted areas are probably small, sizeable sediment-flux events may still result, because the extended period of hydraulic isolation allows considerable sediment accumulation. The maximum area of bed occupied by meltwater at the highest levels of discharge must be less than $100 \%$ of the lattice area, a condition which would lead to the glacier decoupling from the bed. (a)

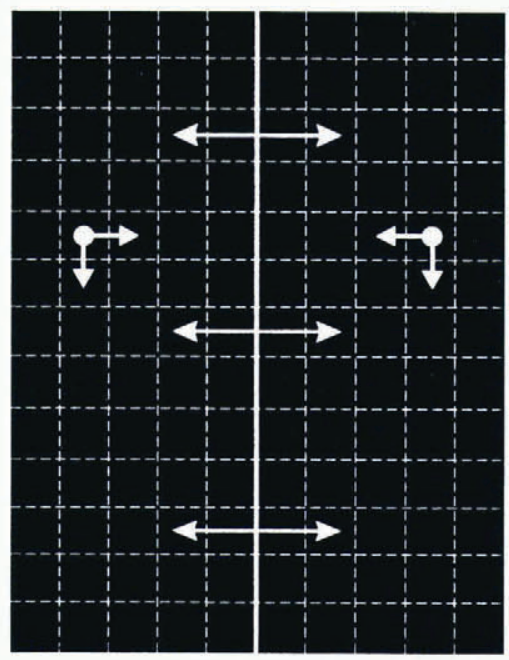

(b)

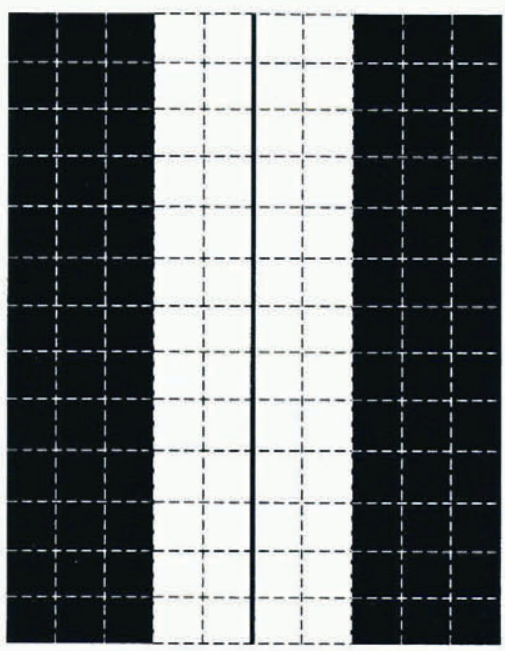

(c)

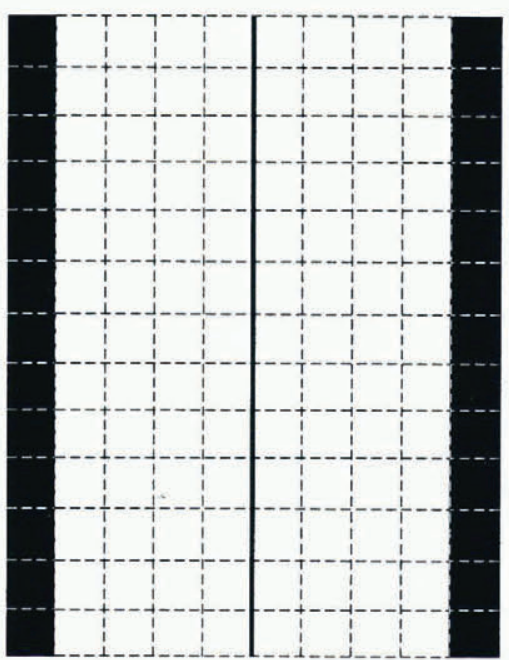

Fig. 3. Plan view of grid-square lattice representing the subsole of a valley glacier, showing the direction in which the total wetted area expands equally on both sides of the thalweg with increasing discharge (long arrows), and longitudinal and transverse directions in which stored sediment is deformed (short arrows) in the model. Shaded areas indicate presence of sediment storage at the subsole, the area retaining sediment declining as increases in discharge expand the wetted area between the end of winter (a), through spring (b) to maximum flow in summer $(c)$. 
Sediment will therefore continue to accumulate throughout summer in unwetted cells at the outer edges of the lattice (Fig. 3c). Cells from which winter sediment accumulation has already been flushed will be recharged during periods in summer when discharge remains low and the margins of the wetted area have regressed towards the thalweg. Such small summer recharge quantities will be removed by the next sufficient increase in wetted area.

The relationship between the number of cells wetted and discharge has to be prescribed. Some possible rating curves in which total wetted area increases to less than $100 \%$ of the total number of squares at the maximum observed discharge are shown in Figure 4. Curve iii allows large quantities of sediment to be removed by the highest flow events, as wetted area increases rapidly at higher discharges. Curve ii gives little increase in sediment flux as flow first rises, say in June, but then allows large flux events to occur at middle discharges, i.e. in early July.

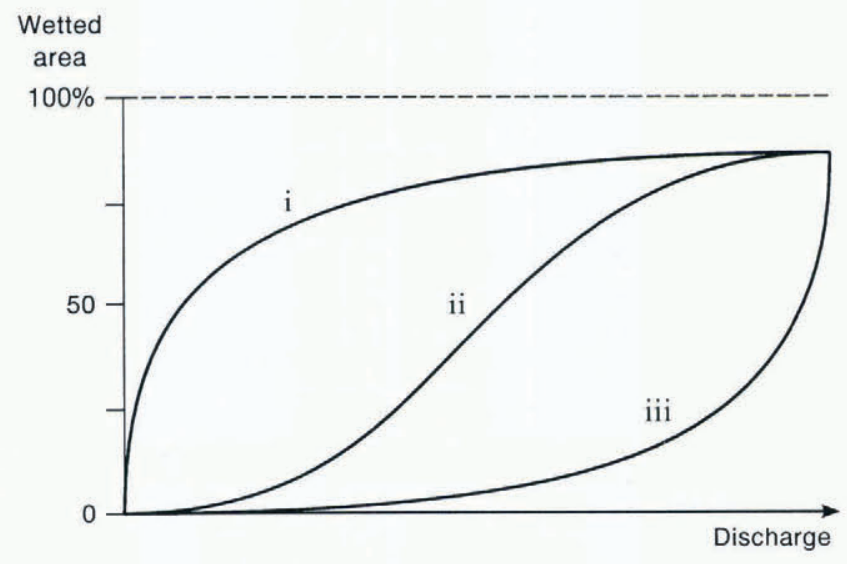

Fig. 4. Possible rating relationships between discharge and wetted area of the subsole.

\section{Background sediment flux}

The model so far described produces sediment transport only during periods of rising discharge. Between such periods the background level of sediment flux is zero. Processes continuously contributing small quantities of sediment at channel margins, therefore, also have to be invoked. At the outer margins of the grid, outside the extent of the zone flushed by the highest discharge, sediment always continues to accumulate. A mechanism is needed to redistribute that sediment. These processes are modelled by allowing sediment to be squeezed from a cell to adjacent cells, either down-glacier, parallel with the direction of sliding, or orthogonally towards the thalweg, as indicated in Figure 3a.

Assuming equal rates of sediment deformation in the longitudinal $(L)$ and transverse $(T)$ directions in a $1 \mathrm{~d}$ time increment, continuity relationships concerning abrasion rate and transfer of sediment from cell to cell can be defined for three types of cell. For a cell $(i, j)$ at the outer margin of the grid (cell d in Figure 5), the change in sediment storage $S$ is given by

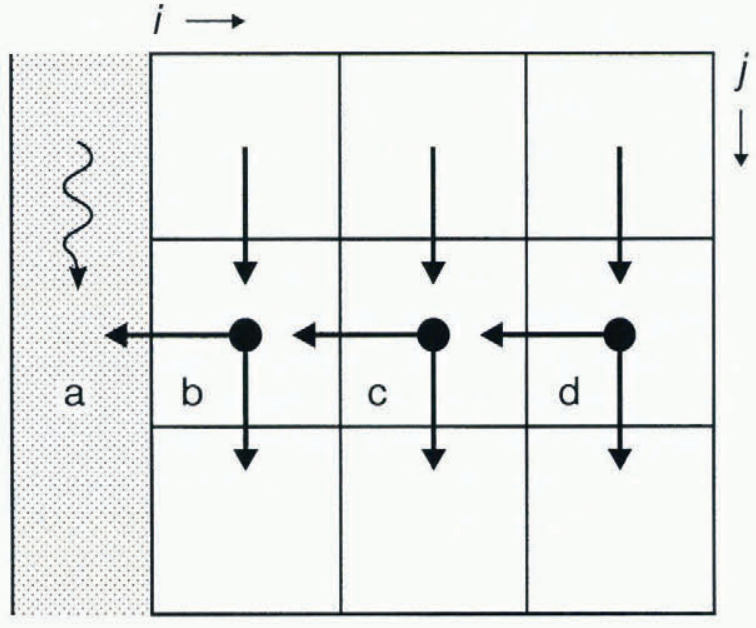

Fig. 5. Pathways in the model by which basal sediment is squeezed from cell to cell and from cell to filament of flow.

$$
\frac{\mathrm{d} S}{\mathrm{~d} t}=A_{i, j}+L_{i, j-1}-L_{i, j}-T_{i, j}
$$

For an unwetted cell elsewhere in the centre of the lattice (cell c), then change in storage is

$$
\frac{\mathrm{d} S}{\mathrm{~d} t}=A_{i, j}+L_{i, j-1}+T_{i+1, j}-T_{i, j}-L_{i, j} .
$$

The rate of addition $(C)$ of sediment from a channelmarginal square (b) to a filament of flow (a) over a length of channel margin forming a side of a grid cell is

$$
C=T_{i, j} \text {. }
$$

Assuming that the rates of sediment deformation are uniform in both directions across the entire subsole, Equation (1) simplifies to

$$
\frac{\mathrm{d} S}{\mathrm{~d} t}=A_{i, j}-T_{i, j}
$$

and Equation (2) to

$$
\frac{\mathrm{d} S}{\mathrm{~d} t}=A_{i, j} .
$$

Hence, $C$ is half the overall squeezing rate from a cell $\left(T_{i, j}+L_{i, j}\right)$. The overall rate of squeezing $(T+L)$ must be less than the rate of abrasion $(A)$ to allow some sediment accumulation across the bed. During winter, when flow velocity is too low to entrain sediment, the model accumulates sediment in cells marginal to the thalweg. This accumulation helps to account for relatively high sediment fluxes associated both with events and with background flows in the early part of the melt season.

\section{Model calibration}

The model depends on the use of a suitable abrasion rate and on the hydraulic geometry used to relate overall wetted area of the subsole to discharge. An abrasion rate can be obtained by averaging total annual sediment flow from a glacier over several years and distributing the average flux uniformly over the area of subsole wetted at 
the maximum discharge. As the latter is unknown, a basin-specific rate for Gornergletscher was obtained from mean annual total flux of $10^{2} \mathrm{kt}$ for the period 1983-89 Collins, 1991) by assuming that the sediment flux in the Gornera is derived uniformly from the entire subsole area. This gives an average daily rate of sediment production or abrasion rate of $3.978 \mathrm{t} \mathrm{km}^{-2} \mathrm{~d}^{-1}$. Actually, the average abrasion rate in dry cells must be higher than this, since, during the ablation season, glacial erosion will not be occurring over hydraulically active areas of the subsole, and not all the subsole area will be flushed by meltwater at maximum discharge. A value of $4 \mathrm{t} \mathrm{km}^{-2} \mathrm{~d}^{-1}$ is taken as plausible for the abrasion rate for use in the model.

In open-channel at-a-station hydraulic geometry, the width of the water surface $(w)$ in a cross-section is related to discharge $(Q)$ :

$$
w=a Q^{b}
$$

usually with the exponent $b<0.3$, as changes in $Q$ can also be accommodated by changes in depth (and velocity) (e.g. Dingman, 1984). This relationship gives a useful simple approximation of the change in the number of wetted squares with discharge, the parameters of which can be optimised in the model. A logistic growth model is an appropriate alternative. An upper value of wetted area has to be specified for the highest observed discharge in order to keep the glacier grounded. The larger the number of cells in the model, and hence the smaller the sediment recharge rate per cell, the more sensitive is sediment flux to discharge.

Starting the model on 1 October 1986, in the $235 \mathrm{~d}$ before runoff commences in late May 1987, $64.747 \mathrm{kt}$ of sediment accumulates over the entire area of the bed. However, more than $130 \mathrm{kt}$ of sediment was flushed from beneath Gornergletscher in the measurement period alone in 1987. A small amount of additional sediment is produced in the ablation season by abrasion in unwetted areas of the bed, but nevertheless, an initial amount of storage of sediment is necessary to prevent complete exhaustion of sediment flux before the end of the ablation season. The implication is that the high flow of late August 1987, which probably covered a large proportion of the subsole with flowing meltwater, removed sediment that had remained in storage since winter 1985/86 at least. An initial total sediment accumulation of $70 \mathrm{kt}$ distributed equally between the cells was therefore assumed in order to "warm-start" the model.

A sensible value for $C$, the rate of addition of sediment by deformation into subglacial meltwater per unit length of channel margin, is difficult to obtain. Since $C$ is taken as time-invariant, and in the model grid the total length of channel margin remains constant throughout the range of discharge, seasonal variation in background sediment flux cannot be represented realistically. An indication of the actual variation of background sediment flux in the Gornera is given by average measured values for 1987 (Table 1).

\section{MODEL RESULTS AND DISCUSSION}

Without incorporation of sediment deformation, the
Table 1. Mean observed background suspended-sediment flux in the Gornera in periods between flux events in 1987

\begin{tabular}{lc}
\hline Month & $\begin{array}{c}\text { Mean flux } \\
\mathrm{ktd}^{-1}\end{array}$ \\
\hline June & 0.577 \\
July & 1.178 \\
August & 0.841 \\
September & 0.415 \\
\hline
\end{tabular}

model represents the temporal pattern of sediment-flux events well through the interaction of meltwater spreading out over and removing stored sediment from the subsole. Taking discharge and sediment flux in the Gornera in 1987 as an example, the good match in timing of the modelled to the measured sediment-flux events is illustrated in Figure 6. It was assumed that $90 \%$ of the glacier subsole was wetted at maximum discharge. The percentage of the grid area integrated with flow $(p)$ in the example is then given by the rating relationship

$$
p=67.45(Q-0.82)^{0.25} \text {. }
$$
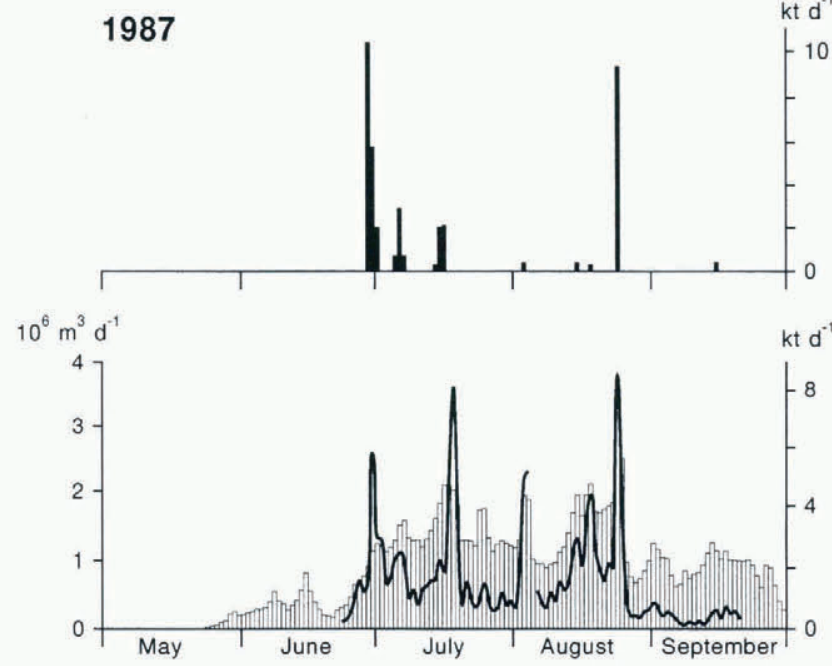

Fig. 6. Measured (lower) and modelled (upper) sediment-flux events together with meltwater discharge (columns) in the Gornera in 1987.

As indicated, while the overall model produces peaks of sediment flux which match the timing of the principal measured events, the rating curve fails to reproduce faithfully absolute and relative sizes of individual events, although magnitudes of the modelled flux events fall within the measured range. The modelled sediment flux at the start of the season during the event on 29 June 1987 is exaggerated. Use of a logistic area-discharge rating function will reduce the magnitude of flux events at relatively low flows. The large sediment-flux peaks measured on 17 July and 3-4 August are seriously underestimated by the use of Equation ( 7 ) as the rating 
curve. The flux peak on 17 July was influenced by a rainstorm, runoff from intense precipitation during which may have entrained sediment from faces of lateral moraines. Previously unwetted areas of subsole towards the sides of Gornergletscher may have been integrated with flow as runoff generated by the rainfall may have initiated new channels leading from the glacier margins towards existing wetted and sediment-swept areas centred on the thalweg. Drainage of the Gornersee on 3-4 August presumably allowed lake-water access to sediment stored on the subsole adjacent to the lake. Although discharge had previously exceeded that reached during the draining of the lake, sediment was flushed from a marginal zone between the lake and the limits of the area integrated with flowing meltwater earlier in the season. In general, even with fairly crude parameter estimation, the model simulates the temporal distribution of events well. The importance of level of discharge and length of time since the previous occurrence of a discharge of a particular magnitude in determining sediment flux in meltwaters draining temperate glaciers is emphasised by the model experiment.

The measured seasonal variations in background sediment flux suggest that the total length of channel margin, across which basal sediment is deformed into filaments of flowing meltwater, varies during the ablation season. As indicated for 1987 in Table 1 and for 1987-90 in Figure 1, background levels of sediment flux doubled during expansion of the drainage network at the start of the season, before declining to a level lower at the end of summer than at the outset. The model treats the wetted area of bed as contiguous, and variation of that area with discharge as the expansion and contraction of a single large filament of flow, which, while clearly adequate for generating the timing of flux events, maintains total channel-margin length constant. For a given wetted area, total channel-margin length will be greater the more crenulated the margins and more subdivided the single filament of flow into separate pathways.

Some possible channel topological-plan configurations with various total channel-margin lengths, yet with the wetted area occupying the same proportion $(40 \%)$ of the cells in the model lattice, are shown in Figures $3 \mathrm{~b}$ and $7 \mathrm{a}-\mathrm{c}$. Division of one wetted area centred on the thalweg (Fig. 3b) into two channels displaced to each side (Fig. 7c) doubles the length of channel margin. However, the model allows squeezing of sediment in two directions only, aligned with glacier sliding and orthogonally towards the thalweg. Hence, division of the wetted area into two provides no increase in the length of channel margin across which sediment can be squeezed into meltwater by comparison with the single area. Sediment would in fact be deformed away from the margin on the thalweg side of a channel. If sediment is allowed to deform in any direction across a cell boundary marginal to a wetted cell, then length of active channel margin would be doubled.

Relative lengths of active channel margin for single and double straight-channel margins, crenulated (meandering) margins (Fig. 7b) and the margins of a $40 \%$ wetted area made up of anastomosing channels (Fig. 7a) for bi- and multi-directional deformation are given in Table 2. Total length of channel margin increases from (a)

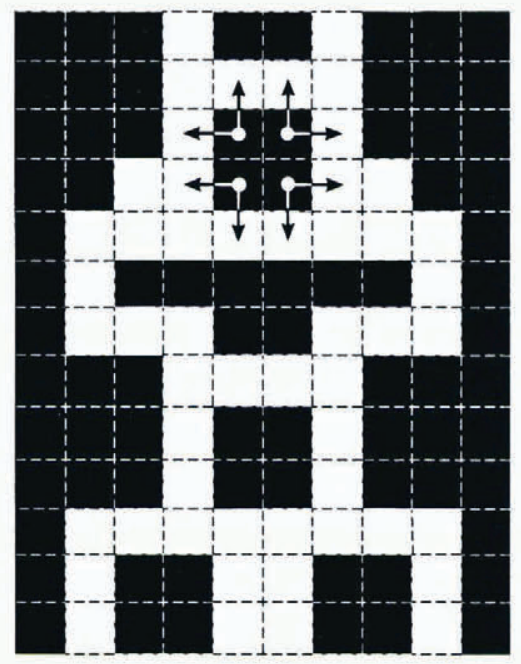

(b)

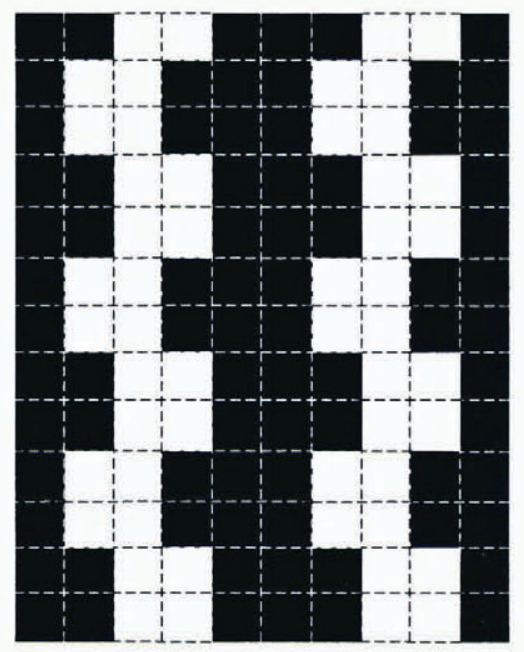

(c)

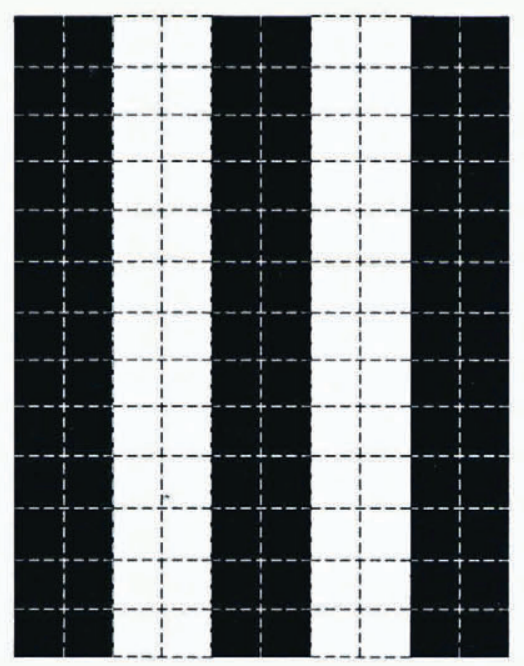

Fig. 7. Various plan configurations in which water covers $40 \%$ of the area of grid lattice. Shaded areas indicate presence of sediment storage at the subsole. Total length of channel margin decreases from anastomosing (a) through crenulated or meandering (b) to straight (c) channel patterns. The arrows indicate the directions in which sediment deformation into water occurs if squeezing occurs across all boundaries of cells adjacent to flowing water.

straight parallel-sided through crenulated or meandering to anastomosing channel patterns. Although multidirectional sediment deformation from cells adjacent to 
Table 2. Relative total length of active channel margin for various plan configurations of $40 \%$ wetted area for bi- and multi-directional deformation of basal sediment

\section{Plan configuration Figure Bi-directional Multi-directional}

$\begin{array}{llll}\text { Single area } & 3 \mathrm{~b} & 1.0 & 1.0 \\ \text { Twin channel } & 7 \mathrm{c} & 1.0 & 2.0 \\ \text { Crenulated twin } & 7 \mathrm{~b} & 1.7 & 2.9 \\ \text { Anastomosing } & 7 \mathrm{a} & 1.9 & 3.4\end{array}$

flowing water increases the length of active channel margin, the rate at which sediment is squeezed in each direction will be reduced. This will have an impact on total sediment supply to meltwater and hence on sediment flux. These considerations support the concept that the subglacial drainage system initially consists of an expanding arborescent network of many small channels, becoming simplified to fewer large conduits as the ablation season progresses, for which there is some evidence elsewhere from dye-tracer tests (e.g. Hock and Hooke, 1993). Subglacial hydrological and sediment-flux events occur at critical points in both the expansion and rationalisation of the basal drainage system, as suggested by Walder (1986) and Collins (1989).

Other factors whould be taken into account in a conceptually based model. The rate of abrasion is unlikely to be constant throughout the season. Since abrasion rate is related to glacier sliding velocity (Hallet, 1979), which is faster in spring, when large quantities of meltwater penetrate inefficient subsole drainage passageways, than in summer and winter (Iken and others, 1983; Iken and Bindschadler, 1986), then basal sediment production will be enhanced in spring. The quantity of sediment accumulated at the subsole will therefore rapidly increase in spring and early summer. A thick layer of deforming basal sediment may generate more sediment or may inhibit abrasion. The amount of sediment accumulated may influence the rate of deformation of basal sediment. It is unlikely that a uniform sediment layer accumulates. Interaction with a distributed subglacial drainage network would suggest that a patchy irregular basal sediment layer is probable.

\section{CONGLUSION}

An attempt has been made to formulate a model which represents the interaction between the subglacial processes through which meltwater flowing at the sole of a glacier acquires suspended sediment from the products of glacial erosion. The model has to be validated by its performance in simulating both suspended-sediment flux events and background flux levels in meltwaters draining from a glacier. The timing of flux events from Gornergletscher, if not the absolute and relative quantities of sediment involved, is modelled well by a basic interaction between a prescribed rating-curve linking area of subsole wetted with discharge, and an inferred uniform constant abrasion rate. The match in time between modelled and observed events suggests that the principal elements of the model are conceptually sound. Modelled flux-event magnitudes within the observed range were produced without recourse to optimisation of the rating curve and abrasion rate.

Background sediment-flux levels, occurring at times between flux events, were not included in the basic model. Differential entrainment of sediment particles by size according to velocity of flow has also yet to be considered.

Temporal changes in how the pattern and size of wetted area fluctuate with discharge also need to be incorporated in the model in order to reflect seasonal variation in background sediment flux. Many separate filaments of flow undoubtedly arise in place of the one contiguous area used in the basic model. When flow decreases, the residual wetted area may be displaced from the original position, and on expansion "fresh" areas of bed away from the margin of the existing wetted area may become integrated with flow if new channels develop. Discharge-related movements of wetted area are suggested by the presence in the records of (small) sediment-flux events at levels in the sequence of discharge peaks at which wetted area should have encompassed only zones of subsole from which the winter accumulation of sediment had already been removed.

Nevertheless, the model confirms that both length of time since the previous occurrence of a particular discharge level, and the difference in magnitude of flow between an event and previous discharge maxima in the series, influence both the timing of flux events and the amount of sediment evacuated. There is considerable potential for the use of this simple conceptually based model, with calibration, in analyses of sediment-discharge relationships in meltwaters draining from temperate glaciers.

\section{AGKNOWLEDGEMENTS}

The author gratefully acknowledges the following assistance: Grande Dixence S.A. for discharge records from the Gornera and logistical support; members of the Alpine Glacier Project for help with field-work; the Royal Society for grants from the Overseas Field Research Grants scheme; and the U.K. Natural Environment Research Council for grant GR3/7265.

\section{REFERENGES}

Collins, D. N. 1979. Sediment concentration in melt waters as an indicator of erosion processes beneath an Alpine glacier. J. Glaciol., $23(89), 247-257$.

Collins, D. N. 1989. Seasonal development of subglacial drainage and suspended sediment delivery to melt waters beneath an Alpine glacier. Ann. Glaciol., 13, 45-50.

Collins, D.N. 1990. Seasonal and annual variations of suspended sediment in meltwaters draining from an Alpine glacier. International Association of Hydrological Sciences Publication 193 (Symposium at Lausanne 1990-Hydrology in Mountainous Regions I: Hydrological Measurements; the Water Cycle), 439-446.

Collins, D. N. 1991. Climatic and glaciological influences on suspended sediment transport from an alpine glacier. International Association of Hydrological Sciences Publication 203 (Symposium at Vienna 1991 Sediment and Stream Waters Quality in a Changing Environment: Trends and Explanation), 3-12. 
Collins, D. N. 1995. Rainfall-induced high-magnitude runoff events in late summer in highly glacierised Alpine basins. British Hydrological Society Fifth National Symposium, 3.55-3.59.

Dingman, S. L. 1984. Fluvial hydrology. New York, W. H. Freeman and Co.

Gurnell, A. M. and C. R. Fenn. 1984. Box Jenkins transfer function models applied to suspended sediment concentration-discharge relationships in a proglacial stream. Arct. Alp. Res., 16 1), 93-106.

Hallet, B. 1979. A theoretical model of glacial abrasion. J. Glaciol., $2389), 39-50$.

Hock, R. and R. LeB. Hooke. 1993. Evolution of the internal drainage system in the lower part of the ablation area of Storglaciären, Sweden. Geol. Soc. Am. Bull., 105 4), 537-546.

Iken, A. and R.A. Bindschadler. 1986. Combined measurements of subglacial water pressure and surface velocity at Findelengletscher,
Switzerland: conclusions about drainage system and sliding mechanism. J. Glaciol., 32(110), 101-119.

Iken, A., H. Röthlisberger, A. Flotron and W. Haeberli. 1983. The uplift of Unteraargletscher at the beginning of the melt season - a consequence of water storage at the bed? .7. Glaciol., 29(101), 28 47.

Ostrem, G, 1975. Sediment transport in glacial meltwater streams. In Jopling, A. V. and B. C. McDonald, eds. Glaciofluvial and glaciolacustrine sedimentation. Tulsa, OK, Society of Economic Paleontologists and Mineralogists, 101-122.

Walder, J. S. 1986. Hydraulics of subglacial cavities. J. Glaciol., 32 (112), $439-445$.

Walder, J. S. and A. Fowler. 1994. Channelized subglacial drainage over a deformable bed. J. Glaciol., 40 (134), 3-15. 